\title{
An Examination of Fifth Grade Students' Attitudes Towards Social Studies Course in Terms of Severable Variables
}

\author{
Selçuk Ilgaz ${ }^{1}$ \\ ${ }^{1}$ Education Faculty, Ataturk University, Erzurum, Turkey \\ Correspondence: Selçuk Ilgaz, Education Faculty, Ataturk University, Erzurum, Turkey.
}

Received: March 3, 2018

Accepted: April 11, $2018 \quad$ Online Published: May 15, 2018

doi:10.5539/jel.v7n4p154

URL: https://doi.org/10.5539/jel.v7n4p154

\begin{abstract}
The aim of this research is to investigate the 5th grade students' attitude towards social studies course regarding several variables. The population of the study consisted of 4435 fifth grade students studying in public schools in Malatya, Yeşilyurt. The sample group consisted of 362 students from 10 schools in the same district. The data used in this study were obtained from the social studies attitude scale and was analyzed with SPSS program. As a result of this research, 5th grade students have a positive attitudes towards social studies lesson and this attitudes are different according to 5th students' teachers' gender, type of school, fall semester points, but this attitudes is the same considering 5th grade students' gender, parents' level of education and taking social studies course.
\end{abstract}

Keywords: attitude, 5 th grade, social studies

\section{Introduction}

Attitude in general is individual's predisposed state of mind regarding a value, event, phenomenon, or object (İnceoğlu, 2011, p. 16). Attitudes have three main elements: affective component, cognitive component, and behavioural component. Cognitive component involves a person's belief and knowledge about the attitude object, the affective component involves a person's emotions/feelings about the attitude object, and the behavioural component is the person's behaviour to the object. The components of the attitudes are related to each other (İnceoğlu, 2011, pp. 29-39). There is a consistent relationship between the components of the attitudes; however, there might be inconsistent relationships between them. For example, people know that smoking cigarette is hazardous for health and although they are not happy because they smoke, they continue to smoke as behaviour (Demirtaş-Madran, 2012, p. 4).

Attitudes form and also change in individuals' life in time due to the influence of some factors (family, friends, teachers, and environment). Children are very much affected by their family's attitudes in their adolescence period and they form their attitudes until they are 30 and after that, they cannot change them very easily (Tavşanc1l, 2010, p. 80).

Individuals usually display their behaviours parallel to their attitudes. Knowing a person's attitudes can help us predict their behaviours (İnceoğlu, 2011, p. 181). However, in order to establish a consistent relationship between attitudes and behaviour, attitudes must be measured correctly (Tavşancıl, 2010, p. 102). In addition to using many methods to measure the attitudes, attitude scales are most commonly used. Expressions reflecting the person's inner world are included in attitude scales and they help to learn the person's true feelings (Tavşancil, 2010, p. 103).

Attitude which forms the basics of human behaviour is not only the focus of sociology and psychology but also it has become a subject of interest for other fields of social sciences (İnceoğlu, 2011, pp. 13-14) because the concept of attitude plays a key role in understanding many concepts (Demirtaş-Madran, 2012, p. 2). Many concepts in social studies are related to attitude. (Yılmaz \& Çolak, 2012) Educational sciences included in these disciplines are one of the fields which examine attitudes in detail because one of the subjects which educational sciences focus on is the changes in student behaviour.

It is expected that a student who is active during the process of learning should have positive attitudes towards school and lessons in order to be involved in the process. Within this context, students' attitudes towards social studies course which they studied in the secondary school are expected to be positive. Students are influenced by 
various factors like content, classroom and school environment, books, peers, and teachers and thus determining their attitudes towards social studies course. Hence, while it is anticipated that individuals display positive behaviours to any object, it is essential that precautions must be taken to learn individuals' attitudes towards an object and to cause them to change their attitudes towards positive, if necessary.

Considering that there is a relationship between students' attitudes and achievements (Altıntaş, 2005, p. 6; Oğur, 2009, p. 77; Demir, 2010, p. 92; Y1lmazer ve Demir, 2014, p. 1717; Çepni, 2015, p. 310), it is revealed that attitudes serve as a signal flare to bring success for students. In addition to cognitive entry characteristics as stated by Bloom, affective domain characteristics including attitude influence learning so entry characteristics must be measured well and evaluated more elaborately. Thus, learning process will have been managed in a much more controlled manner (Fidan, 2012, pp. 102-103). Therefore, while planning the education process, it is important that students' attitudes towards social studies are considered as attitudes affect students' learning either positively or negatively.

Among the foreign research studies carried about students' attitudes towards social studies course are Schug et al. (1982), Chiodo \& Bayford (2004), Khaled (2013), Dundar \& Rapoport (2014), Ahmed \& Maryam (2016) and Öztürk \& Baysal (1999), Akengin, Sağlam, \& Dilek (2002), Tay \& Akyürek Tay (2006), Ergin (2006), Sidekli (2010), Yaşar \& Gürgoğan Bayır (2010), Kılınç \& Dere (2015) can be included in domestic research studies. While students' attitudes towards social studies course differ in the research studies carried out abroad, it is found in our country that students' attitudes towards social sciences course were generally positive.

\section{The Purpose and Importance of the Research Study}

The purpose of this research is to investigate the 5th grade students' attitude towards social studies course regarding several variables. The main goals of education are that students should actively participate, they should have a desire to learn, and they should be successful in their lesson during the learning process. With the changing of curriculum in 2004, traditional education model was replaced by a new learning process that included students' affective characteristics in the process. Teachers are asked to use attitude scales and also they are recommended to take necessary precautions for students to display positive attitudes in social studies curriculum. What a teacher can do to change a student's attitude is limited to his own opportunities. Teachers' individual works are limited to their own classes, but this situation negatively affects publishing houses, curriculum designers, education administrators, and universities which also considers students' attitudes. Thus, as a result of increase of such studies and publication of their results, every institution and organization will have an opportunity to do their parts in their own areas.

In line with this purpose, the statement of the problem is as follows: What are the attitudes of the 5th grade students with several variables towards social studies course?

\section{Method}

Based on quantitative research design, descriptive model was used in the study. Descriptive model is used to describe information concerning the current status of the phenomena. The current status is presented without being changed or trying to be changed but as it is (Karasar, 2012, p. 77).

\subsection{The Population and the Sample}

The population of the study consisted of 44355 th grade students studying in formal state secondary schools and imam hatip secondary schools in Malatya, Yeşilyurt.

The size of the sample to be used in the study were calculated as 354 with a formula $n=N t^{2} \mathrm{pq} / \mathrm{d}^{2}(\mathrm{~N}-1)+\mathrm{t}^{2} \mathrm{pq}$ determined by Yazıcıoğlu \& Erdoğan (2011). The sample group consisted of 362 students chosen randomly from 10 state and imam hatip secondary schools located in Malatya, Yeşilyurt.

\subsection{Data Collection Tools and Data Collection}

A questionnaire was used as a data collection tool in the research study. The data which were used to determine students' attitudes towards social studies course were obtained via implementation of student demographic information form which included several variables of students and "Attitude Scale for Social Studies Course" developed by Özkal (2002) to the 5th grade students in classroom environment. Attitude Scale for Social Studies Course consisted of 315 point Likert-type items and its Cronbach's Alpha reliability coefficient was found as 0,91 (Özkal, 2002, p. 55).

The data obtained from the study were coded and entered to SPSS statistical package program and then the data were analysed. The positive items in the attitude scale about social studies course were entered as Strongly Agree (5), Partially Agree (4), Neutral (3), Disagree (2), Strongly Disagree (1); the negative items were coded as 
Strongly Agree (5), Partially Agree (4), Neutral (3), Disagree (2), Strongly Disagree (1). Before each test, whether or not hypotheses were proved was checked and then the test was implemented in order to test the data within the scope of the research's stated goals and sub-goals. The independent samples t-test, one of the parametric tests for comparison of two groups, was used for the normal distribution of the data, one-way ANOVA for comparison more than two groups was used, and Kruskal Wallis H Test, one of the non-parametric tests for comparison of more than two groups, was used for non-normal distributions in the research study.

\section{Findings}

\subsection{Investigation of the 5th Grade Students' Attitudes towards Social Studies Course}

Statistical information considering the items of the Attitude Scale for Social Studies Course displaying the attitudes of the 5th grade students towards social studies course and the whole was presented in Table 1.

Table 1. Statistical information on the 5th grade students' attitudes towards social studies course

\begin{tabular}{|c|c|c|c|}
\hline $\begin{array}{l}\text { Item } \\
\text { Number }\end{array}$ & Attitude Scale for Social Studies Course & $\overline{\mathbf{X}}$ & SD \\
\hline 1 & I mostly like Social Studies course among the other courses. & 4.04 & 1.14 \\
\hline 2 & Social Studies course is one of the three courses that I like most. & 4.12 & 1.34 \\
\hline 3 & I feel sleepy in Social Studies course. & 4.22 & 1.35 \\
\hline 4 & I get bored while studying Social Studies course. & 4.12 & 1.36 \\
\hline 5 & I'm looking forward to bell ringing in Social Studies course. & 3.96 & 1.49 \\
\hline 6 & Social Studies course is among the courses I like most. & 4.21 & 1.34 \\
\hline 7 & I feel comfortable in Social Studies course. & 4.17 & 1.3 \\
\hline 8 & I don’t want to attend Social Studies course. & 4.43 & 1.18 \\
\hline 9 & I don't study Social Studies course willingly even during the exams. & 4.39 & 1.21 \\
\hline 10 & I listen to Social Studies course to some extent, and then I can't. & 4.25 & 1.34 \\
\hline 11 & I daydream in Social Studies course. & 4.31 & 1.24 \\
\hline 12 & I will be happy if there are fewer subjects in Social Studies course. & 3.7 & 1.61 \\
\hline 13 & I am scared of Social Studies course. & 4.48 & 1.19 \\
\hline 14 & I will be very happy if Social Studies course is excluded from the curriculum. & 4.3 & 1.32 \\
\hline 15 & Social Studies course does not have an important place in my daily life. & 4.62 & 0.94 \\
\hline 16 & I feel tired after Social Studies course. & 3.91 & 1.5 \\
\hline 17 & I feel tired when I start to study Social Studies course. & 4.12 & 1.38 \\
\hline 18 & I feel relax when Social Studies unit finishes. & 3.63 & 1.64 \\
\hline 19 & Social Studies course is a very boring course. & 4.34 & 1.26 \\
\hline 20 & Social Studies course is very entertaining. & 4.17 & 1.34 \\
\hline 21 & Time does not fly in Social Studies course. & 3.8 & 1.58 \\
\hline 22 & I want more Social Studies course hours. & 3.51 & 1.64 \\
\hline 23 & $\begin{array}{l}\text { I try to learn subjects which are difficult to understand in Social Studies course without } \\
\text { getting bored. } \\
\text { I constantly want to benefit from my teachers and peers to increase my knowledge of Social }\end{array}$ & 4.18 & 1.29 \\
\hline 24 & Studies course. & 4.33 & 1.16 \\
\hline 25 & I like to revise subjects related to Social Studies course in my free time. & 3.98 & 1.35 \\
\hline 26 & I like to revise subjects related to Social Studies course when I go home. & 3.92 & 1.37 \\
\hline 27 & I study Social Studies course less than my friends. & 4.23 & 1.26 \\
\hline 28 & Studying Social Studies course relaxes me. & 3.65 & 1.51 \\
\hline 29 & I try to do my best in Social Studies course. & 4.66 & 0.94 \\
\hline 30 & I often think what I learn in Social Studies course. & 4.11 & 1.29 \\
\hline \multirow[t]{2}{*}{31} & I do questions about Social Studies course in my free time. & 3.99 & 1.34 \\
\hline & General & 4.12 & 0,94 \\
\hline
\end{tabular}

According to the items of the Attitude Scale for Social Studies Course, when the attitude means were examined, generally most items have similar means. The items with the lowest mean scores are item number 22 which states, "I want more Social Studies course hours." $(\overline{\bar{x}}=3.51)$, and item number 18, "I feel relax when Social Studies unit finishes." ( $\bar{x}=3.63)$, item number 28, "Studying Social Studies course relaxes me." $\left({ }^{\bar{x}}=3.65\right)$. On the other hand, the items with the highest mean scores are item number 29, "I try to do my best in Social Studies course." $\left(\hat{\bar{x}}_{=4.66)}\right.$ and item number 15 ," Social Studies course does not have an important place in my daily life." $(\bar{x}=4.62)$. The 5th grade students make an effort to succeed in social studies course and they are aware of the importance of social studies course in daily life. In addition, 5th grade students think that course hours for social 
studies are adequate and they do not want the course hours to increase. They also think that they feel relieved when the social studies units are finished and social studies course is boring and difficult.

While social studies course teachers state that time allotted for social studies course is not enough (Karacaoğlu \& Acar, 2010) in the research studies carried out, the 5th grade students in this study are not in favour of increasing the course hours.

When Table 1 is analysed, the mean scores of the data obtained from the attitude scale implemented with the 5th grade students are presented. The 5-point Likert-type scale was rated with a minimum of 1 and a maximum of 5, with a range of 0.8. The range of 1-1.80 represents Strongly Disagree, 1.81-2.60 represents Partially Diagree, 2.61-3.40 represents Neutral, 3.41-4.20 represents Partially Agree, and 4.21-5.00 represents Strongly Agree. Considering this, the attitude mean scores of the 5th graders are 4.12 and this indicates to the range of 4.12. As a result, it can be stated that 5th grade students' attitudes towards social studies course were positive.

The finding of this research study which stated that the 5th grade students' attitudes towards social studies course were positive coincides with the findings of Akengin et al. (2002), Ergin (2006), Tay \& Akyürek Tay (2006), Sidekli (2010), Yaşar ve Bayır (2010), Kılınç \& Dere (2015). That is, the findings of this study support the other research findings carried out in our country.

4.2 Investigation of the 5th Grade Students' Attitudes Towards Social Science Course With Regard to the Type of Schools (Secondary /Imam Hatip Schools) They Studied at

Statistical information displaying the attitudes of the 5th grade students towards social studies course in terms of types of schools they studied at and t-test results was presented in Table 2 .

Table 2. Descriptive statistics and t-test results of the 5th grade students' attitudes towards social studies course with regard to the types of schools (secondary /imam hatip schools) they studied at

\begin{tabular}{lllllll}
\hline Type of School & $\mathbf{n}$ & $\overline{\mathbf{X}}$ & SD & $\mathbf{t}$ & $\mathbf{d f}$ & $\mathbf{p}$ \\
\hline Secondary School & 297 & 4.24 & .75 & \multirow{2}{*}{4.87} & \multirow{2}{*}{80.29} & \multirow{2}{*}{.00} \\
İmam Hatip Secondary School & 6.5 & 3.60 & 1.00 & & & \\
\hline
\end{tabular}

Independent samples t-test was performed to determine whether or not the 5th grade students' attitudes towards social studies course changed in terms of the types of schools they studied at. According to this, the attitudes of the 5th grade students studying at normal secondary schools towards social studies course $\left({ }^{\bar{x}}=4.24\right)$ were higher than the attitudes of the 5th grade students studying at imam hatip secondary (Religious) schools $(\bar{x}=3.60)$ and there was a statistically significant difference $\mathrm{t}(80.29)=4.87, \mathrm{p}=.00$. Eta Squared effect size is 06 and it refers to a small effect size.

\subsection{Investigation of the 5th Grade Students' Attitudes Towards Social Science Course With Regard to the Student Genders}

Statistical values and test results considering whether or not the 5th grade students' attitudes towards social studies course changed in terms of their genders were presented in Table 3.

Table 3. Descriptive statistics and t-test results of the 5th grade students' attitudes towards social studies course with regard to the students' genders

\begin{tabular}{lllllll}
\hline Gender & $\mathbf{n}$ & $\overline{\mathbf{X}}$ & SD & t & df & p \\
\hline Female & 190 & 4.15 & .85 & .52 & \multirow{2}{*}{360} & .60 \\
Male & 172 & 4.10 & .81 & & & \\
\hline
\end{tabular}

Independent samples t-test was performed to determine whether or not the 5th grade students' attitudes towards social studies course changed in terms of students' genders. Considering that, students' attitude scores towards social studies course do not change with regard to students' genders $\mathrm{t}(360)=.52, \mathrm{p}=.60$. While the findings of this study support the research findings of Ergin (2006), Sidekli (2010), Kılınç \& Dere (2015), the findings are inconsistent with the research findings of Tay \& Akyürek Tay (2006) which stated that the female students had higher attitudes. 
4.4 Investigation of the 5th Grade Students' Attitudes Towards Social Science Course with Regard to the Their Mother's Level of Education

Statistical information and test results with regard to the 5th grade students' attitudes towards social studies course in terms of their mothers' level of education were presented in Table 4.

Table 4. Statistical information of the 5th grade students' attitudes towards social studies course in terms of their mothers' level of education

\begin{tabular}{llcc}
\hline Mother's Level of Education & $\mathbf{n}$ & $\overline{\mathbf{X}}$ & SS \\
\hline Illiterate & 31 & 4.31 & .74 \\
Primary School & 93 & 4.08 & .82 \\
Secondary /Primary Education & 113 & 4.01 & .95 \\
High School & 93 & 4.21 & .73 \\
University & 32 & 4.22 & .80 \\
\hline
\end{tabular}

Table 5. One-Way ANOVA results of the 5th grade students' attitudes towards social studies course in terms of students' mother's level of education

\begin{tabular}{llllll}
\hline & Sum of Squares & df & Mean of Squares & F & p \\
\hline Between the groups & 3.80 & 4 & .95 & & \\
Within the groups & 248.41 & 357 & .70 & 1.37 & .25 \\
Total & 252.21 & 361 & & & \\
\hline
\end{tabular}

One-way ANOVA was implemented in order to learn whether or not the 5th grade students' attitudes towards social studies course changed with regard to their mother's level of education. The test results revealed that the students' attitudes towards social studies course did not change with regard to their mother's level of education, $\mathrm{F}(4.361)=1.37, \mathrm{p}=.25$. The findings of this research study support the research findings of Ergin (2006).

4.5 Investigation of the 5th Grade Students' Attitudes Towards Social Science Course with Regard to the Their Father's Level of Education

Kruskal Wallis H Test Results for the 5th grade students' attitudes towards social studies course with regard to students' father's level of education were exhibited in Table 6.

Table 6. Kruskal Wallis H Test results for the 5th grade students' attitudes towards social studies course with regard to students' father's level of education

\begin{tabular}{llllll}
\hline Father's Level of Education & $\mathbf{N}$ & Mean Rank & SD & $\mathbf{X}^{\mathbf{2}}$ & $\mathbf{p}$ \\
\hline Illiterate & 8 & 244.56 & & & \\
Primary School & 55 & 160.62 & & & \\
Secondary/Primary Education & 107 & 194.77 & 4 & 7.23 & .12 \\
High School & 109 & 179.79 & & & \\
University & 83 & 174.40 & & & \\
\hline
\end{tabular}

Kruskal Wallis H Test was administered in order to learn whether or not the 5th grade students' attitudes towards social studies course changed with regard to their fathers' level of education. According to the results of Kruskal Wallis $\mathrm{H}$ test, the 5th grade students' attitudes towards social studies course did not change with regard to their father's level of education; $\mathrm{X}^{2}(4)=7.23 ; \mathrm{p}=.12$.

4.6 Investigation of the 5th Grade Students' Attitudes Towards Social Science Course with Regard to Their Fall Semester Points

Statistical values and test results of the 5th grade students' attitudes towards social studies in terms of their fall semester points were presented in Table 7 and Table 8 . 
Table 7. Descriptive statistics of the 5th grade students' attitudes towards social studies course with regard to their fall semester points

\begin{tabular}{llll}
\hline Fall Semester Points & $\mathbf{n}$ & $\overline{\mathbf{X}}$ & SD \\
\hline $1-44$ & 3 & 3.55 & 1.36 \\
$45-54$ & 15 & 3.6 & .71 \\
$55-69$ & 50 & 3.91 & .86 \\
$70-84$ & 121 & 4.10 & .88 \\
$85-100$ & 173 & 4.25 & .77 \\
\hline
\end{tabular}

Table 8. One-Way ANOVA results of the 5th grade students' attitudes towards social studies course with regard to their fall semester points

\begin{tabular}{llllll}
\hline & Sum of Squares & df & Mean of Squares & F & p \\
\hline Between the groups & 9.972 & 4 & 2.493 & & \\
Within the groups & 242.238 & 357 & .679 & 3.67 & .01 \\
Total & 252.209 & 361 & & & \\
\hline
\end{tabular}

One-way ANOVA was administered in order to learn whether or not the 5th grade students' attitudes towards social studies course changed with regard to fall semester points. Considering that, the 5th grade students' attitude scores for social studies course were statistically significant; $\mathrm{F}(4.361)=3.67, \mathrm{p}=.01$. Eta Squared effect size is 04 and it refers to a small size effect. According to the Post Hoc Tukey test results administered to learn between which groups there was a significant difference, the attitude scores of the 5 th grade students whose fall semester points were between 85 and $100(\bar{X}=4.25)$ were higher than those with fall semester points between 45 and $54(\dot{x}=3.6)$. The findings of this study support the research findings of Öztürk \& Baysal (1999), Tay \& Akyürek Tay (2006) and Ergin (2006).

4.7 Investigation of the 5th Grade Students' Attitudes Towards Social Science Course with Regard to Their Teachers' Genders

Statistical information and test results of the 5th grade students' attitudes towards social studies course in terms of their teacher's genders were presented in Table 9.

Table 9. Descriptive Statistics and T-test results of the 5th grade students' attitudes towards social studies course with regard to their teacher genders

\begin{tabular}{llcclll}
\hline Teacher's Genders & $\mathbf{N}$ & $\overline{\mathbf{X}}$ & SD & t & df & p \\
\hline Female & 224 & 4.36 & .70 & \multirow{2}{*}{6.74} & \multirow{2}{*}{236.13} & \multirow{2}{*}{.00} \\
Male & 138 & 3.75 & .91 & & & \\
\hline
\end{tabular}

Independent samples t-test was performed to determine whether or not the 5th grade students' attitudes towards social studies course changed in terms of teacher's genders. The test results revealed that the attitudes of the 5th graders who were taught by a female teacher had higher scores towards social studies course $(\bar{x}=4.36)$ than the 5 th grade students' attitude scores $(\bar{x}=3.75)$ whose teacher was a male and this difference is significantly meaningful, $\mathrm{t}(236.13)=6.74, \mathrm{p}=.00$. Eta Squared effect size is 11 and it refers to a medium effect size. The finding of the study which revealed that the students who were taught social studies course by female teachers had positive attitudes towards the course supports the reserach findings of Ergin (2006).

4.8 Investigation of the 5th Grade Students' Attitudes Towards Social Science Course with Regard to Taking Courses

Statistical information and T-test results of the 5th grade students' attitudes towards social studies course in terms of students' attending a course in social studies were given in Table 10.

Table 10. Descriptive statistics and t-test results of the 5th grade students' attitudes towards social studies course with regard to students' attending a course in social studies

\begin{tabular}{lllllll}
\hline Taking Course & $\mathbf{n}$ & $\overline{\mathbf{X}}$ & SD & $\mathbf{t}$ & $\mathbf{d f}$ & $\mathbf{p}$ \\
\hline Participants & 75 & 4.26 & .80 & \multirow{2}{*}{1.53} & \multirow{2}{*}{360} & .12 \\
Non-participants & 287 & 4.09 & .84 & & & \\
\hline
\end{tabular}


Independent samples t-test was performed to determine whether or not the 5th grade students' attitudes towards social studies course changed with regard to attending a course in social studies. According to the test results, the students' attitudes towards social studies course did not show any change with regard to attending courses in social studies, $\mathrm{t}(360)=1.53, \mathrm{p}=.12$.

\section{Results and Suggestions}

\subsection{Results}

The following results were obtained from the research study carried out to investigate the 5th grade students' attitudes towards social studies course with regard to several variables:

The 5th grade students have positive attitudes towards social studies course. The result obtained supports the results of Akengin et al. (2002), Ergin (2006), Tay \& Akyürek Tay (2006), Sidekli (2010), Yaşar \& Bayır (2010), K1lınç \& Dere (2015). The 5th grade students studying in normal secondary schools had higher positive attitudes towards social studies course than the attitudes of the 5th graders studying in imam hatip secondary schools. In fact, the 5th grade students studying in imam hatip secondary schools had negative attitudes towards social studies course when compared to normal secondary schools.

The 5th grade students' attitudes towards social studies course do not change with regard to gender and parental level of education. While the result that the 5th graders' attitudes do not change with regard to gender supports the results of the research study conducted by Ergin (2006), Sidekli (2010), it contradicts with the result of the study by Tay \& Akyürek Tay (2006) which states that female students had higher attitudes.

The 5th grade students' attitudes towards social studies course change with regard to their false semester points as stated by the students, but the attitudes of students with scores between 85 and 100 are more positive than those with false semester scores between 45 and 54. That is, the successful students' attitudes towards social studies course are much higher. The result of the study supports the results of research studies carried out by Öztürk \& Baysal (1999), Tay \& Akyürek Tay (2006) and Ergin (2006).

The 5th grade students' attitudes towards social studies course change with regard to the gender of social studies course teacher and the students who had a female social studies course teacher had more positive attitudes towards the course. This result is compatible with the research results of Ergin (2006).

The 5th grade students' attitudes towards social studies course do not change with regard to their taking courses related to social studies course. That is, the 5 th graders who do not attend the social studies course and those who attend the course share the same attitudes towards the social studies course.

\subsection{Suggestions}

The following suggestions can be made in line with the results obtained from the investigation of the 5th grade students' attitudes towards social studies course.

Scientific research studies should be conducted with the 5th grade imam hatip secondary school students who had more negative attitudes towards the social studies course than the students studying in normal schools in order to improve their attitudes towards social studies course and also to determine the factors that cause these attitudes of students. Moreover, more effort and awareness rising is needed to increase the students' attitudes.

The 5th grade students' attitudes towards social studies course differed with regard to the gender of social studies course teacher. Thus, the behaviours of social studies course should be investigated in detail. The teachers should be informed by analysing the reasons for the low attitudes of the 5th grade classes in which male social studies teachers taught and students' attitudes should be increased positively.

Because most of the subjects in social studies course were abstract, they cause students to get bored during the lesson and while studying. That's why different activities should be used more while teaching the lesson to improve their attitudes towards social studies course. The abstract concepts in social studies course must be concretized and even dramatized while teaching them. Thus, the students will take the opportunity to learn with fun and this will promote positive attitudes towards social studies course.

\section{References}

Altintaş, S. U. (2005). Ilköğretim 7. sinif öğrencilerinin sosyal silgiler dersine yönelik tutum düzeyleri. Sosyal Bilimler, 3(2), 1-12. Celal Bayar Üniversitesi S.B.E. Manisa.

Çepni, O. (2015). Ortaokul öğrencilerinin sosyal bilgiler dersine yönelik kaygi ve tutumlarinin ç̧eşitli değişkenler açisindan incelenmesi. ZfWT Zeitschrift für die Welt der, 7(2), 299-313. 
Chiodo, J. J., \& Byford, J. (2004). Do they really dislike social studies? a study of middle school and high school students. Journal of Social Studies Research, 28(1), 16-26.

Demir, A. (2010). İlköğretim II. kademe öğrencilerinin sosyal bilgiler dersine ilişkin tutumlari ile akademik başarilari arasinda iliş̧ki (şanliurfa ili örneği) (Unpublished master’s thesis). Harran Üniversitesi Sosyal Bilimler Enstitüsü Şanlıurfa.

Demirtaş-Madran, H. A. (2012). Tutum, tutum değişsimi ve ikna. Ankara: Nobel Akademik Yayıncılık.

Dündar, Ş., \& Rapoport, A. (2014). Elemantary Students' Attitudes Toward Social Studies, Math, And Science: An Analysis With The Emphasis On Social Studies. The Councilor: A Journal of the Social Studies, 75(2), $1-11$.

Ergin, A. (2006). İlköğretim ögrrencilerinin sosyal bilgiler dersine ilişskin tutumlari (Unpublished master's thesis). Pamukkale Üniversitesi Sosyal Bilimler Enstitüsü Denizli.

Fidan, N. (2012). Okulda öğrenme ve ögretme. Ankara: Pegem Akademi Yayınları.

Hamza, A., Sağlam, D., \& Dilek, A. (2002). Ilköğretim 4. ve 5. sinif öğrencilerinin sosyal bilgiler dersi ile ilgili görüşleri. M.Ü. Atatürk Eğitim Fakültesi Eğitim Bilimleri Dergisi. Say1: 16. Sayfa: 1-12.

İnceoğlu, M. (2011). Tutum algi iletişim. Ankara: Siyasal Kitabevi.

Karacaoğlu, Ö. C., \& Acar, E. (2010). Yenilenen Programların Uygulanmasında Öğretmenlerin Karşılaştı̆ı Sorunlar, Yüzüncü Yll Üniversitesi Eğitim Fakültesi Dergisi, VII(I), 45-58.

Khaled, A. F. (2013). Jordanian Students Attitudes Toward Social Studies Education. The Journal of International Social Research, 24(6), 227-236.

Kilinç, E., \& Dere, İ. (2015). 5th Grade Students' Attitudes Toward Social Studies During The 4+4+4 Educational System. Eğitimde Kuram ve Uygulama, 11(3), 989-1003.

Ministry of National Education (Turkish Republic). (2005). Social studies 6th-7th classes programme.

Oğur, M. (2009). Altıncı ve yedinci sinif öğrencilerinin sosyal bilgiler dersine yönelik tutumlarinin incelenmesi (Unpublished master's thesis). Pamukkale Üniversitesi Sosyal Bilimler Enstitüsü.

Özkal, N. (2002). Sosyal bilgiler dersine yönelik tutum ölçeğinin geliştirilmesi. Eğitim ve Bilim, 27(124), 52-55.

Öztürk, C., \& Baysal, N. (1999). Ilköğretim 4-5. sinif öğrencilerinin sosyal bilgiler dersine yönelik tutumlari. Pamukkale Üniversitesi Ĕgitim Fakültesi Dergisi, 6, 11-20.

Schug, M. C., Todd, R. J., \& Beery, R. (1982). Why kids don't like social studies. Kaynak. Retrieved from http://files.eric.ed.gov/fulltext/ED224765.pdf

Sidekli, S. (2010). İlköğretim beşinci sinif öğrencilerinin 2004 programi doğrultusunda sosyal bilgiler dersine karşi tutumlari. Sosyal Araştırmalar Dergisi, Aralık.

Tavşancil, E. (2010). Tutumlarin ölçülmesi ve spss ile veri analizi. Ankara: Nobel Yayın Dağıtım.

Tay, B., \& Akyürek Tay, B. (2006). Sosyal bilgiler dersine yönelik tutumun başariya etkisi. Gazi Üniversitesi Türk Eğitim Bilimleri Dergisi, 4(1), 73-84.

Umair, A., \& Shaista, M. (2016). Secondary school students' attitude towards the social science studies in sargodha city, Pakistan. International Journal of Academic Research in Progressive Education and Development, 5(2), 67-76. http://dx.doi.org/10.6007/IJARPED/v5-i2/2093

Yaşar, Ş., \& Gürgoğan B. Ö. (2010). İlköğretim 5. sinif öğrencilerinin bakiş açisiyla sosyal bilgiler. e-Journal of New World Sciences Academy, 5(3), 1213-1225.

Yazicioğlu, Y., \& Erdoğan, S. (2011). Spss uygulamali bilimsel araştirma yöntemleri. Ankara: Detay Yayıncılık.

Yılmaz, K., \& Çolak, R. (2012). Sosyal bilgiler öğretiminde kavram haritalari kullaniminin öğrencilerin tutum, akademik başari ve bilgilerinin kalicilik düzeylerine etkisi. Cumhuriyet Uluslararası Eğitim Dergisi, 1(1), $1-16$.

Yilmazer, A., \& Demir, S. B. (2014). Ortaokul öğrencilerinin sosyal bilgiler dersine ve sosyal bilgiler öğretmenine karşi tutumlari ile akademik başarilari arasindaki ilişkinin incelenmesi. Turkish Studies, 9(2), 1705-1718. http://dx.doi.org/10.7827/TurkishStudies.6449 


\section{Copyrights}

Copyright for this article is retained by the author(s), with first publication rights granted to the journal.

This is an open-access article distributed under the terms and conditions of the Creative Commons Attribution license (http://creativecommons.org/licenses/by/4.0/). 